\title{
Urgences
}

\section{Une rivière...}

\section{Marc Gagnon}

Numéro 15, octobre 1986

Épigraphiques

URI : https://id.erudit.org/iderudit/025332ar

DOI : https://doi.org/10.7202/025332ar

Aller au sommaire du numéro

Éditeur(s)

Urgences

\section{ISSN}

0226-9554 (imprimé)

1927-3924 (numérique)

Découvrir la revue

Citer ce document

Gagnon, M. (1986). Une rivière... Urgences, (15), 70-70.

https://doi.org/10.7202/025332ar

Ce document est protégé par la loi sur le droit d'auteur. L'utilisation des services d'Érudit (y compris la reproduction) est assujettie à sa politique d'utilisation que vous pouvez consulter en ligne.

https://apropos.erudit.org/fr/usagers/politique-dutilisation/ 


\section{Marc Gagnon}

Les rivières sont des chemins qui marchent, et qui portent où l'on veut aller.

Blaise Pascal: Pensées, 17

Une rivière.

Un chemin.

Une voie.

Qui porte et transporte.

Où l'on plonge, s'allonge et s'attarde.

Qui se glisse, coule et s'attarde.

Qui marche, serpente, ondule, module.

À l'ombre ou sous les arbres.

De l'ombre jusqu'à la mer.

Belle comme la pluie.

Souriante comme le printemps.

Vibrante. Mouvante.

Belle. Froide. Indolente.

Vive. Plus vive encore.

Agitée. Précipitée. Tumultueuse.

Ténébreuse.

Belle. Grave. Douce. Sereine. Confidente.

Qui porte où l'on veut aller,

Souvent plus loin et même ailleurs.

Qui porte où elle veut aller,

Par détours. Par grands détours.

Sans retour.

Fidèle. Infidèle. Enivrante.

Envoutante.

Qui chante et qui danse et plaisante.

De jour comme de nuit.

Une femme. 